\title{
The University of Sydney
}

\section{Michael Wilding}

\section{Teaching writing}

They sat in the Korean Barbeque. Dr Bee's dead cow sizzled on the grill on the table, succulently for Dr Bee, noxiously for Pawley. Henry expressed no opinion. It had been indicated to him that his opinions were better left unexpressed. Unanimously indicated by the Writers' Centre Director, by the Festival Director, by the Ministries, both Arts and Health, and, historically, by the University. He sat in momentary silence. Pawley had ordered dol sot bibim-bab. Without meat. Egg?

'Up to four eggs a week are good for you,' Dr Bee informed them.

'They used to be bad for you,' said Henry.

'They've changed their mind. They've found they actually reduce cholesterol,' said Dr Bee.

'So do pistachio nuts,' said Pawley.

'I do not see them on the menu,' Dr Bee observed.

Pawley accepted egg. He couldn't bring himself to ask if it was free range.

Henry had followed Pawley and ordered bib-im-bab without the meat. He was avoiding red meat these days. More belated following of medical advice.

They shared a shallot pancake and Pawley closed his mind to the seafood in it. He displaced his anxiety into stirring the bib-im-bab furiously with his chopsticks to mix in the egg.

'And how is life in the world of arts control?' Dr Bee asked.

Henry broke his silence.

It was, he informed them, yet again, a world of its own, preoccupied with its own agendas. A fast growing endlessly busy network, a career path, an industry in itself. Whenever anyone wanted to justify government funding for the arts, they always came up with the argument for employment.

'Not control?' queried Pawley.

'Control?' 
'That is the hidden agenda,' said Pawley. 'The inexpressible. The concealed purpose.'

'Hardly concealed,' said Dr Bee. 'Seems pretty obvious to me.'

'Arts funding provides jobs,' Henry informed them.

'Jobs for administrators,' said Dr Bee.

'If only,' said Henry. 'It's worse than that. Now they bang on about jobs for artists. Arts organizations are being geared to organize workshops for artists to teach. Never mind that they might not want to teach. Never mind that they would be happier occupied in writing or painting or performing or whatever they do best. Workshops and mentorships are mandatory because they provide employment, and employment is something that always concerns government bureaucrats. The government bureaucrats speak to the arts bureaucrats and they are all of one mind and one vocabulary.'

'Debased as it is.'

'Absolutely,' Henry agreed. 'And what they want is regular employment. None of this lazing on the beach and getting inspiration. None of this sitting at home drinking instant coffee and writing poems.'

'What about leisurely literary lunches?' Pawley asked.

'Absolutely not.'

'Verboten.'

'In a word,' said Henry. 'Get the bastards employed.'

'A revival of the nineteenth century workhouse principle,' Pawley observed, always one for the historical context. 'Gather the poor and indigent and oppressed and deranged and provident and sick -'

'How well you characterise the literary community,' said Dr Bee.

'- and put a roof over their heads and make the bastards work. Teach, wantons, teach.'

'Appalling,' Dr Bee agreed. 'A fate worse than death.'

'Yet we did it,' Pawley remarked.

'That was different,' said Henry. 'We taught literature. All these people are teaching creative writing courses. And not just at the Writers' Centre. At universities. Schools. Correspondence colleges. Everywhere.'

'One senses a certain disapproval from your tone,' Dr Bee noted, waving a sliver of cow at him with his chopsticks.

'Disapproval?' said Henry. 'I'm appalled. They'd all be much better off reading books.'

'The teachers? Or the students?'

'All of them.'

'What sort of books?' 
'Real books,' said Henry. 'Good books.'

'Your books?'

There was no denying it. Henry did not even attempt to.

'It was a happier world when there were fewer writers and more readers,' said Henry.

'For you.'

'Nothing wrong with solipsism,' said Henry.

'It's a disaster now,' he continued. 'In the past people took literature courses.'

'Shakespeare. Milton.'

'Of course. But they would be studying some modern literature too. The novel.'

'Your novels.'

'Sometimes.'

'Though not often enough.'

Henry demurred.

'In what sort of numbers?' Dr Bee asked.

'Oh, you know -'

'I don't. That is why I'm asking.'

'It depended on the size of the class. Ten, twenty people maybe. If you got a text on a first year course, though, it could be seven hundred copies a year for three years.'

'Did you?'

'Bastards,' said Henry.

'I take that as a no.'

'And now,' said Henry, '187,000 students a year study creative writing. Think of the books they could have been buying.'

'Instead of writing their own.'

'It could have added up to millions.'

'And instead you inspired them with the wish to write.'

'I inspired them?'

'By your example. The louche glamour of your life. The wealth. The women. The drugs. The status.'

'They're too young to be writing. They should be reading. Learning how to write by reading.'

'Reading their betters.' 
'There is no other way.'

'And you read your betters?' Dr Bee inquired.

Henry gave him a hard look.

'I did teach literature for thirty something years.'

'Till you began teaching creative writing.'

'That was because they'd cancelled my literature courses. Bastards.'

It kept flooding back to him, the way his solicitous colleagues had 'rested' his courses, to use their hypocritical term. Like locking them away in a mental asylum till all memory had been obliterated by electric shock therapy.

'And do you still read in retirement?' Dr Bee asked.

'Don't use the R word,' Pawley reminded them.

'In whatever phrase Henry prefers to describe his current state.'

'"Full time writer" seems to be the preferred term,' Pawley offered.

Henry grunted.

'You don't like it?'

'Sounds a bit déclassé.'

'As if you have to write for your living?' Dr Bee suggested. 'Not the gentlemanly thing.'

'A slave to market forces,' Pawley glossed.

'I think people now would think that would be a good thing. Market forces rule supreme. No,' Henry continued, 'It's more a matter of not giving the impression of financial worry.'

'You prefer to imply a private income,' Dr Bee offered. 'Anything but work.'

'I think a stigma still attaches to the concept of honest toil,' said Henry.

'So you don't propose to do any.'

'The cult of the inspired amateur still holds sway?' Pawley asked.

'I don't know about amateur,' said Henry.

'But inspired?'

'Of course,' he agreed, shamelessly. 'And it's not that I don't work.'

'Two hours a day,' said Dr Bee. 'That, I believe you told us, is the writer's working day.'

'The sensible ones,' said Henry.

'There are others who do more?'

'Yes, but do more than that, and it's no good.' 
'Too hard? End up missing lunch?' Dr Bee inquired.

'No, the work's no good.'

'Is that so?'

'Definitely. Writers aren't concert pianists or gymnasts. They don't have to put in an eight hour day.'

'Who does an eight hour day now?' Pawley asked. 'That's all gone. First country in the world to introduce the eight hour day, and now everyone's working twelve, fifteen hours a day.'

'Except for writers,' Dr Bee reminded him.

'Except for writers.'

'But they still call it work.'

'It's the intensity of it,' said Henry.

'Never mind the length, what about the quality?'

'Exactly.'

'Nice to be so precise,' said Dr Bee.

'It is,' Henry agreed. 'Anyway,' he continued, 'I have no guilt on that score. I've put in my time. Now, I have to tell myself, there is no necessity to force myself to keep on. I've done plenty. I've got plenty lined up waiting to publish. Why not reduce the stress?'

'And then you get stressed thinking about the 180,000 students a year not buying your books,' said Pawley.

'187,000,' Henry corrected him. 'Anyway, I'm not saying that some of them don't buy them,' he added, authorial wisdom holding sway, never imply a fading readership.

'But not enough.'

'Enough,' he insisted.

'But not as many as if they were forced to. By your presence on a list of set texts.'

'Exactly,' Henry agreed.

'You'd rather they learned to read but not to write. A policy proposed in Britain in the 1870 s when compulsory education was being introduced. Teach the working classes to read instructions from their betters, but don't give them the techniques of writing back.'

'Of course I'm not proposing that.'

'Though it has some merit as an idea,' Dr Bee suggested.

'If you're implying there's a political conspiracy behind it all,' Henry said, 'for once I agree with you.' 
'Of course there is,' said Pawley. 'There always is. Control. The most efficient way of control is ignorance. If you degrade education so no one learns anything, no one knows anything; there is no need for censorship. Your students just never encounter the radical history, the radical writers, the alternative, the choices; they don't even know the past existed or that there were any books in the past. Their ignorance serves to suppress the advances of the centuries. It's a calculated policy of dumbing down. Divert the young from reading books. Divert the middle-aged for that matter. That way they never encounter any subversive ideas. Any ideas, full stop. Creative writing is a way of occupying syllabus time, adult education time, at the expense of political education.'

'Bugger political education,' said Henry. 'I'm talking about literature.'

'Literature is political education,' said Pawley. 'That's why it's being run down in the universities. And in the culture generally.'

'And if it's not political education, it's not literature? Is that what you're saying?'

'Objectively, yes,' said Pawley. 'In practice. And it's all about practice.'

They picked at the side dishes, the kim-chi, the broccoli (good for everything, Pawley assured them), the shredded sugared turnip. They sipped at their miso soup. Swigged at their Hite beer.

'As I recall it, Henry,' Dr Bee said, 'weren't you privy to this political decision to introduce creative writing courses and cut out literature, when you introduced creative writing into the university?'

'I was manipulated,' said Henry. 'Looking back on it.'

'You sense a conspiracy,' said Pawley.

'I was invited to America to teach it. Creative writing.'

'America,' said Pawley, in those careful tones in which you referred to the Great Satan.

'Yes, America.'

'You must have done something very bad,' said Dr Bee.

'And when I came back my literature courses had been closed down.'

'Rested,' said Pawley.

'Exactly. So. Even though I wasn't sure it was a good idea, what else could I do? Work up a whole batch of new courses and try and get them approved by the departmental committee? All that reading. New texts. No way.'

'A chance to read your betters,' said Dr Bee.

'But I just wanted to write. I was tired of reading other peoples' books.'

'You were perfect, Henry,' said Pawley.

'I know.'

'You sold out the pass.' 
'Yes.'

'And now there's no one to read your books.'

'It's not as bad as that,' said Henry.

'Isn't it?'

'Objectively,' said Henry, 'No, it isn't.'

'Good one,' said Pawley. 'You've got to think positively. If you think your readers have all gone, then surely they will be gone. What you think about, you draw to you.'

'Is that so?' said Henry.

'Yes.'

'Is that another piece of new age consciousness from the Northern Rivers?' Dr Bee asked. 'Should I think about sex all the time?'

'Don't you anyway?' said Henry.

'It's more the ancient wisdom,' said Pawley, unperturbed.

'Rediscovered,' Henry added.

'I don't believe it was ever lost,' said Pawley. 'The tradition has always been carried forward through the ages. You can't suppress truth.'

'Is that so?'

'You can try. But in the end truth triumphs.'

'But not books,' said Henry.

'Depends how true they are,' said Pawley.

Michael Wilding is Emeritus Professor in the School of Letters, Art \& Media, University of Sydney, and former chair of the NSW Writers' Centre.

\section{TEXT}

Vol 11 No 2 October 2007

http://www.textjournal.com.au

Editors: Nigel Krauth \& Jen Webb

Text@griffith.edu.au 